FROM GENTRIFICATION TO RE-URBANIZATION:

THE EXPANDING TERRAIN OF SOCIO-SPATIAL INEQUALITY

by

Corey J. Horowitz, BA (Hons.), University of Guelph, 2008

\author{
A Major Research Paper \\ Presented to Ryerson University \\ in partial fulfillment of the requirements for the degree of \\ Master of Planning \\ in \\ Urban Development
}

Toronto, Ontario, Canada, 2011 


\title{
FROM GENTRIFICATION TO RE-URBANIZATION: THE EXPANDING TERRAIN OF SOCIO-SPATIAL INEQUALITY
}

(c) Corey J. Horowitz, 2011

\author{
Master of Planning \\ in \\ Urban Development \\ Ryerson University
}

\begin{abstract}
This paper examines a confluence of factors and consequences linked to changing socioeconomic and spatial arrangements in the post-industrial globalized city. Neo-liberal urban governance and the influence of evolved capitalist economic and cultural structures have altered the demographic landscape of many cities. Urban neighbourhoods are increasingly exclusive to the middle and upper classes, as state support for low-income populations wanes in favour of revenue growth and a fixation on image. Gentrification has expanded geographically, and is often promoted by policy with little regard for gradual but substantial displacement of the poor. These patterns are epitomized in large 'world cities' such as New York, London, and Toronto that are the financial and cultural centres of their region; however, the conditions are emergent in a growing number of cities worldwide. If governments are to prevent standardization of these processes and commit to measures for social sustainability, they must first demonstrate greater capacity for intervention in market-based inequalities.
\end{abstract}

Key Words:

Spatial justice; neo-liberalism; urban restructuring; critical theory 


\section{Acknowledgement}

I would like to extend gratitude to my advisor, Dr. Sandeep Agrawal, as well as Lawrence Altrows for his feedback and support. 


\section{TABLE OF CONTENTS}

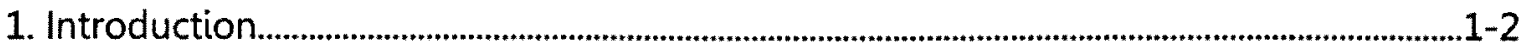

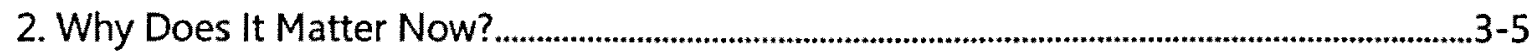

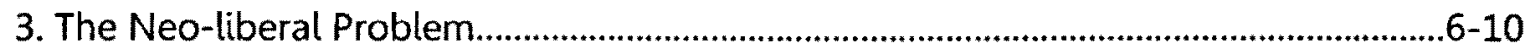

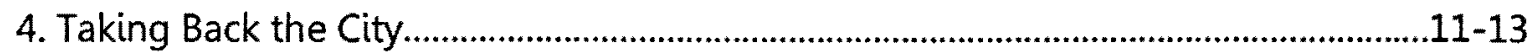

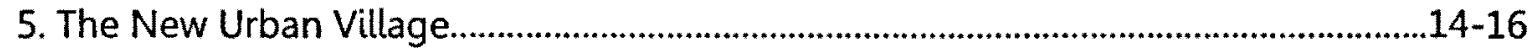

6. Case Study: Postmodernism, Social Mixing, and the CAMH Redevelopment............17-19

6.1 More Determinism at the Junction of Planning and Mental Health.................19-20

6.2 Integration as Therapeutic Capitalism...........................................................20-21

7. The Illusions of Mixed-Income Redevelopment..........................................................22-25

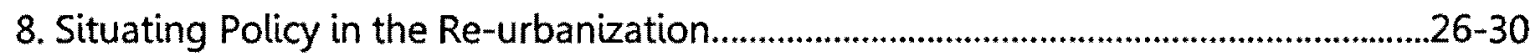

9. Case Study: Parkdale, Housing, and Social Regulation...............................................31-34

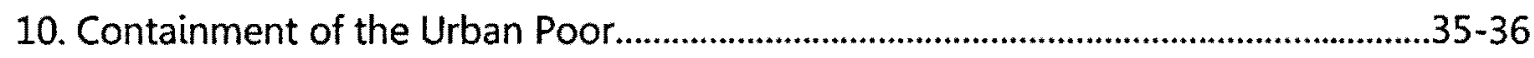

11. Disinvestment in Low-Income Resources...............................................................37-38

12. Planning for Comfort-The Changing Fabric of the Public Realm..............................39-41

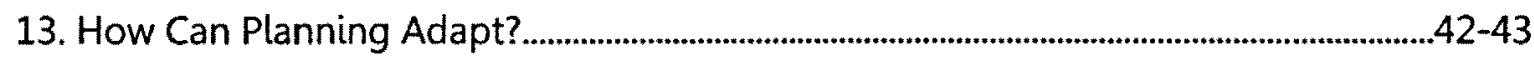

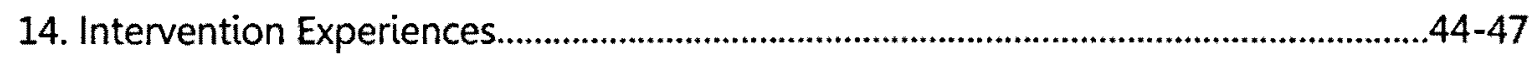

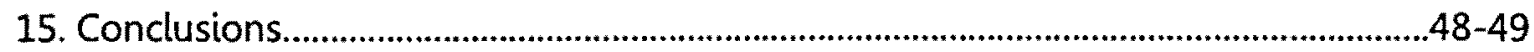

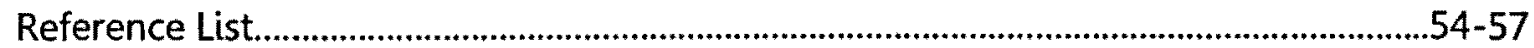




\section{APPENDICES}

1. Hulchanski '3 Cities' maps
a) 1970-2005.
.50
b) 1970 .
.51
c) 2025 . .52

2. Parkdale neighbourhood anti-gentrification flyer.. .53 


\section{Introduction}

Since the dawning of the neo-liberal era, many major post-industrial cities of the global north have exhibited broad patterns suggesting a phenomenon of socio-spatial restructuring. The changes began due to a range of overarching processes including globalization, shifting roles and responsibilities of the state, a transformation of economic and cultural structures, and new priorities of urban space and resource distribution. It is acknowledged from the outset that identifying trends of geographic and social division may go beyond the current evidence. For this reason, the proposition of a large-scale re-urbanization should be regarded ostensibly as a theoretical hypothesis to be further developed, rather than assertion as an absolutely-defined process. As another caveat, analysis does not assume total applicability of the trend, but rather the presence of an evolving arrangement of spatially defined poverty and dwindling housing options amongst a contained and marginalized lower-class. In a meta-critique of neo-liberal urban development, this paper will present a synthesis of literatures addressing a multitude of approaches to the problems of urban spatial inequality. Two case studies in Toronto will be used to evidence how several issues are manifested on the ground. A host of other examples from Toronto and similarly situated cities will be employed along the way.

Further enquiry will be directed at identifying and deconstructing the more specific conditions that have brought about the urgency for a recognized spatial category of social justice and a 'right to the city' for all. Inequalities can be produced and compounded by the application of urban planning and development practices, and indeed the policies and agenda of urban governance in general. Housing policy and land-use decisions are increasingly influenced by and reliant on the private sector and free market. A dynamic and ever more important relationship between city and suburb/exurb now exists, with important cultural and demographic changes occurring. Though different cities display different spatial organizations, the marginalization of the urban poor and low-income populations has become almost 
universal urban experience, taking place via forces of geographic repression and/or an informal push to the urban fringes (Davis, 1998; Shaw, 2008b). As the urban landscape becomes increasingly prioritized and commodified for 'higher order' usage, a growing segment of the population is excluded from access to once viable housing options, and the appropriation or maintenance of space and neighbourhood.

We must ask whether a dangerously large portion of the 'global city' is becoming exclusive to a homogenous socio-economic class, as a hegemony of political, cultural, and economic interests seem to supersede the well-being of a growing underclass. Within the lexicon of spatial justice and critical urban theory, an implication of policy and planning praxis in the need for intervention should emerge. If urban planners, policy makers, agents of community development, and other concerned actors can cement these issues in their collective consciousness and dialect, they have taken the first step in beginning to address change formally. 


\section{Why Does /t Matter Now?}

Among the major motivators of gentrification prominent in the literature are three categories of explanation. The economic/production side hinges on the relationship of capital investment to the production of new urban spaces and users (Smith, 1996). The cultural or consumption side contends that social and cultural forces influence new appropriations of place. Lastly, the globalization or 'world city' theory (Sassen, 1991) links gentrification with changing economic structures, the heightened mobility of capital, and associated competition between cities. But conception of the distinct, more encompassing, and more troubling entity of re-urbanization does not involve a perspective operating from one predominant explanation, but the confluence and supplementation of contributing processes from these and other areas of research.

The issue here is not just typical gentrification. It is on a larger scale; and to a greater impact. More than just single line trends of gentrification, it is a re-urbanization that may be what Neil Smith (1996) has called 'gentrification generalized'. One way to interpret this is the expansion, normalization, and increased promotion of the process in various forms. This is particularly relevant in the way that policy has embraced gentrification (often in revitalization or redevelopment plans), as seen in London, England, the United States, Australia, the Netherlands, (Davidson, 2008), and in Toronto, among other places (Davidson, 2008; Walks \& August, 2008).

According to Tom Slater (Shaw, 2008a), we have also witnessed an "eviction of critical perspectives" from gentrification research and discourse. The growing interest in stated goals of inclusion and integration, and subsequent inattention to displacement is likely connected to the adoption of neo-liberal policy aimed at 'positive gentrification' (Shaw, 2008a). Wacquant (2008) echoes this concern, adding that research and policy fixating on cultural goals has contributed to relative class indifference and its spatial correlates. The relationship between 
augmented gentrification and policy, and the context of redevelopment, renewal, and 'social mixing' initiatives will be elaborated in later sections.

'Gentrification generalized' is also invoked by a reinvestment in the urban core and extension of the gentrification umbrella. No longer restricted to a specific process or segment of the market (e.g. fixing up of old inner-city homes by the upper-middle class and direct displacement), it has come to include tenure conversions, functional conversions (industria//non-residential to residential), and new construction on formerly non-housing sites (Davidson, 2008; Fainstein et al., 1992). Traditional negative connotations of gentrification like rent increases and evictions are now less central (Davidson, 2008). The result is a more systematic form of displacement that may be less overt, but is integral to the restructuring of urban space, not just a bi-product of change (Fainstein et al., 1992).

The trend of increased 'up-scaling' in neighbourhoods of New York City (though it could be applied more broadly) described by Sharon Zukin (2010) has led to a decrease in the low to middle-income housing stock, and more stark socio-economic boundaries between neighbourhoods and districts. Since 1970, the city of Toronto has exhibited growing divisions in the form of a shrinking middle-class, steady decline of naturally-occurring mixed-income neighbourhoods, and a reduction of housing affordable for low and middle income populations (Hulchanski, 2010). A more general but related pattern, likely linked to changes in the urban economy and the rise of neo-liberalism, is a weakening of the traditional workingclass neighbourhood or 'urban village' in favour of more corporatist pastures (Wacquant, 2008; Zukin, 2010). In Toronto the working poor are increasingly housed in areas of disinvestment and highly concentrated, high-density poverty (United Way, 2011). They are pushed to the urban fringes where services and amenities are unsuitable, and/or contained in neglected highrise tower neighbourhoods, a few of which remain in the inner city. The trends of class-based re-urbanization are related to a shifting geography and suburbanization of poverty in Toronto 
(Hulchanski, 2010), and across the metropolitan U.S. (Brookings Institution, 2011; The Economist, 2010).

The new class-character of urban change threatens the authentically urban qualities at the very being of cities everywhere. Once inclusive to social, economic, and (sub)cultural diversity, many global cities are now embracing policies that enable the privatization and increased regulation of public spaces, essentially granting primacy to mainstream consumer/destination culture. There is cause to be wary of practices that are complicit with exclusionary forms of development, which strive to create culturally uniform landscapes of consumption at the expense of more organic and democratic processes. More neighbourhoods are being groomed and prioritized for attracting investment, catering to the comfort of a particular lifestyle and status, while rejecting the needs of those who do not or cannot subscribe. The trend of an upper/middle class return to the city, driven by changing preferences, has been accompanied by public and private reinvestment. But the 'urban renaissance' has human costs, reinforcing barriers and divisions of age, race, and income (Zukin, 2010). 


\section{The Neo-Liberal Problem}

In his influential study of a 1960's working-class urban village in Boston, Herbert Gans (1982) recognized the rootedness of economic and political structures that gave private enterprise a free hand in the highly lucrative and exploitable housing market. Even at this relatively early juncture, the foundation for neo-liberal politics and economics could be seen in the context of neighbourhood change and redevelopment practices. Several factors have combined to create the conditions and perceived necessity for the neo-liberal turn of the urban political economy. Among them are the urban-suburban dynamic and battle for resources/investment; the competition for increasingly mobile capital and investment among globalized and aspiring cities; changes to federal-municipal funding and provisional relationships; and the relentless capitalist pursuit of new and more profitable terrains of economic growth. These explanations are expanded below.

The pattern of middle and upper-class urban flight ('white flight' in many U.S. cities) that characterized the mid to late $20^{\text {th }}$ century had important consequences for cities. This refers not only to residential movement, but also to that of business, industry and capital. Some results for inner-cities were curtailed investment, more low-order or tax exempt land uses, and depleted municipal revenue structures relative to expenditure responsibilities (Gans, 1982). The American example differs from the context of Canadian cities, but they share the effect of population dynamics on this period of urban change. The urban exodus contributed to an increased and rapid suburbanization (Fainstein et al, 1992). Suburban expansion had key social and political impacts. New attitudes formed which tended to favour a withdrawal from investment of public resources into causes of collective action or social spending, spawning an economic conservatism united around 'possessive individualism' (Harvey, 2008), and the protection of homeowner interests (Davis, 1998). In other words, public funds were being diverted from those who needed them most in the city as the politics of redistribution adjusted 
to accommodate a newly potent demographic of voters. In conjunction, urban and suburban $\rightarrow+$ populations became increasingly polarized in their interests. The 1998 amalgamation of the City of Toronto with five surrounding municipalities demonstrates this transition, as large, significantly suburban populations gained equal representation in the governance of urban Toronto.

When a considerable portion of business and industry began favouring location in the suburbs (lower tax rates, land prices, and available space), the urgency arose for cities to attract reinvestment whether through tax subsidies and incentives, redevelopment/revitalization schemes, or general pandering to the interests of private profit and economic growth. Urban decline resulting from suburban investment signalled the loss of a competitive advantage, and triggered a new era of contest for location of the middle-class economic surplus (Davis, 2006). The recent influx of urban investment has come with the preference for a return to city-living among middle classes in the post-industrial metropolis (Zukin, 2010) as their cultural proclivities are accommodated by spatial change. In order to compete with the suburbs for business/tax revenue and the middle-class surplus, urban spaces and processes increasingly yield to attractive investment and consumption landscapes, mobile sources of capital, and people with disposable income. Often this is seen in an elevated concentration of high-end 7 condos and residential or high-profile commercial chain retailers.

In the context of globalization, neo-liberalism has acted as vessel for bringing in more footloose sources of capital (luxury real estate speculation, headquarters for big business, tourism, foreign investment), responding to ever greater pressures on cities to compete on the world stage. The interplay between globalization and neo-liberalism has not only blurred the boundaries between national and regional borders, but also between city neighbourhoods at the local level (Zukin, 2010). In an urban economy that is now less rooted in industry, and more dependent on the knowledge and service sectors, business is less confined to a specific place. 
Investment doesn't need to come from local sources or within the neighbourhood. It can afford to come from anywhere in the city or beyond. An international development firm may become interested in building condos in a modest, working-class neighbourhood because of its easy access to downtown. The urban agenda of revitalization and growth, and rising demand for urban living and real estate contribute to the likelihood of this happening. Commercial and residential gentrification (and associated housing/living costs), once limited in its breadth, flows outward from the core, cascading down the urban hierarchy and adding new spaces of tension (Shaw, 2008b). The shared economic/real estate strategies of major cities around the world are creating cultural conditions that are more and more similar across place, whereby investment between many cities becomes almost interchangeable (Zukin, 2010).

In the early 1990's, Canada's Federal government abandoned its role as housing provider 4 in heed of the neo-liberal climate, leaving the lower levels of government and their already insufficient resources to take responsibility for housing the poor (Lees $\&$ Ley, 2008). Major cities like York and London are similarly positioned, with the state's departure from or decline in housing responsibilities resulting in a greater influence of the private sector in new housing provision (Fainstein et al, 1992). This transition has meant the onslaught of a new approach to housing policy and (re)development that extends privatization and the application of market principles to formerly public social services, namely affordable and low-income housing (Sharman, 2006). Cities such as Toronto, London, and New York now rely more heavily on partnership with developers and the private sector in a policy regime that already facilitates the up-scaling of neighbourhood real estate, responding not to need but market conditions (Fainstein et al, 1992; Lees \& Ley, 2008).

One thing that many large capitalist economies have in common is the unrelenting need to pursue growth (Homer-Dixon, 2011). With societies moving from economies of production to ones heavily reliant on consumption (Zukin, 2010), the capitalist need to expand the profit 
landscape is all the more pressing. In Los Angeles for example, the last 20 years or so have seen an obsession with gentrifying the downtown, something of a 'downtown renaissance', ridding the area of undesirable strains (the poor and homeless) on real estate profits (Davis, 2006). Urban place and space thus becomes a commodity where conflict arises between its current use value, which may be of low profit/revenue yield, and potential exchange value (of higher order use) (Wacquant, 2008). This reflects the hierarchical ordering of land use in central cities where practices of redevelopment and gentrification prioritize a more revenue-friendly and consumer-oriented environment (Harvey, 2008). The result is often a dispossession of rights for the marginalized populations, if not through direct loss of housing, then of the urban spaces and resources that they have appropriated over time, as outside interest moves in under the guise of city-building (Shaw, 2008).

While one thrust of postmodern urban development has been a greater range of cultural and market niches, this has served mainly to diversify the terrain of profit, and really only benefits those who have the money to spend on new options for consumption (Harvey, 2008). A new mode of 'cultural production' or 'cultural dominant' has emerged under postmodernism, one which encompasses the creative/knowledge economy, the arts, architecture, and the substance of social theory (Jameson, 1991). Jameson identifies a distinct 'late-stage capitalism' characterized by the enhanced fluidity of financial capital (globalized markets and labour, multi-national corporations). A changing spatialization of culture results from postmodernism as an organizer of this capitalist form that also engenders a greater plurality of market culture (ibid).

Changes associated with neo-liberal policy and urban globalization have also generated higher demand for luxury housing in and near city centres, contributing to rising property prices at the top of the market, and the ensuing diffusion of elevated housing and living costs to other neighbourhoods (Fainstein et al, 1992). Investment in the built environment can be a 
very attractive option for large corporations that can afford to build residence exclusively for high-income populations, inevitably to the detriment of affordable options inside the city (ibid). New buildings and conversions of other uses move properties and neighbourhoods up the market, while the growing numbers of those who can no longer afford the area are forced to $\phi[$ move outward and/or down-market (ibid). In Toronto, areas at the market's low end are increasingly those of highly concentrated poverty within the city's inner suburbs (United Way, 2011). In 2006, $46.3 \%$ of Toronto's low-income families lived in areas of high poverty concentration-up from just $17.8 \%$ in 1981-where old, deteriorating, and under-maintained high-rise towers are a prevalent form of housing (ibid). There is clearly a sharpening divide in access to quality housing stock between income levels, as well as in the location of their respective housing within the city (Hulchanski, 2005). 


\section{Taking Back the City}

Just as politics and economics can dictate urban change, social and cultural forces can forge the conditions that make parts of the city ripe for reinvestment and upgrading. The desire for authentic neighbourhood and urban lifestyle has led to an upswing in the popularity of downtown living, especially among young and upwardly-mobile demographics (Zukin, 2010). Such a trend represents not only a catalyst for reinvestment, redevelopment, and rising living costs in many urban neighbourhoods, but also a demographic and class-based shift in the occupation of inner-city housing and space. Changes affected by gentrification are relevant to socio-economic status, but also to age and ethnicity (Walks \& August, 2008). This is certainly true of Toronto, where several old, traditionally ethnic neighbourhoods such as Little Italy (years ago), and more recently Portugal Village, see an influx of a young, typically white, spatially-mobile middle-class moving in (ibid). In Brooklyn, a process of 'ethnic succession in reverse has been occurring where whites move in, blacks and Latinos move out, and a 'Manhattanization' effect brings up-scaling in the form of taller buildings, and a more affluent social character (Zukin, 2010). These changes are no doubt connected to the transitioning, if not already transformed, socio-economic dynamics of such neighbourhoods.

It would seem that in many cities the 'super-rich' appropriate the most central and valuable urban real estate, causing the middle-class to seek affordable housing in adjacent (likely once working-class) neighbourhoods, while former inhabitants are pushed out further in a cycle of the gentry. As seen on the Hulchanski map (2010) (Appendix 1a), the vast majority of Toronto's central area, also with the best subway access, is populated by residents of City 1 (income has increased by $20 \%$ or more since 1970 ). This was not always the case. Appendix $1 \mathrm{~b}$ shows a markedly greater presence of low-income residents in and around downtown in 1970 (ibid). Appendix 1c projects the severity of the situation in 2025 if current trends continue unchanged. A growing rate of previously untouched working-class areas of Toronto possessing 
character and authenticity have become objects of desire for middle-class consumption and home ownership (Walks \& August, 2010). The aforementioned expanded character of gentrification, and inflation in the real estate market, appear to be factors along with a cultural craving for all things urban.

The movement of suburbanites to the city and the staying of potential suburban migrants have also been motivated by a realization of the mismatch between economic privilege and an inappropriate spatial organization of the suburban upper-middle class (Sorkin, 2007). While the preference was once overwhelmingly for status (suburban individualism and class segregation) over convenience (urban scale and services) (Gans, 1982), many residents are now being lured back by new investment and aesthetic upgrading, reflecting the freedom of economic mobility, and ultimately the new reality of spatial privilege. On the back of suburban reform, the New Urbanist movement has also played a part here, particularly in its capacity to satisfy the urban character preference and notions of liveability through an appeal to sensibilities of scale and built form (Sorkin, 2007). In the context of redevelopment, this often comes with ignorance to social and community processes that are beyond the scope of urban design (ibid). The gentrifying city begs the question of whether there is a limit to the residential relegation of low-income groups at the hands of spatial-economic privilege.

In the wake of the energy crisis and the realities of climate change, a departure from suburban ideals has understandably garnered much support behind the drive to reform unsustainable lifestyles and attitudes. This is resoundingly true of developments that engage the agenda of environmental and economic sustainability (adaptive re-use, conversions, retrofitting) (Bunce, 2009). But the social costs of redevelopment may be overlooked. Here in lies a challenge of negotiating the confrontation between two pressing issues of progress; the pursuit of social equity, and the need for an energy-efficient future. More attention to strategies for reconciling the two is required. 
While it is evident that there is adversity associated with the 'urban renaissance', it can easily be marketed as a positive goal. To 'bring people back to the city' was the sentiment espoused by the UK's Labour government in 2000; but Davidson (2008) for one is sceptical, pointing out that it is really just the economically-active upper and middle classes that they are after. Urban policy discourse has adopted a culturally-defined rhetoric of inclusion, ethnic and income diversity, integration, and sustainability that has obscured the class-based nature of urban change, and diverted attention from concrete measures of inequality such as jobs, wages, poverty, education, and income gaps. Wacquant (2008) refers to this as the 'mirage of the cultural turn', in which such language replaces economic indicators in the discourse of spatial change in order to justify and promote gentrification or redevelopment. He goes on to say that, By focusing narrowly on the practices and aspirations of the gentrifiers through rose-tinted conceptual glasses, to the near-complete neglect of the fate of the occupants pushed aside and out by urban redevelopment, this scholarship parrots the reigning business and government rhetoric that equates the revamping of the neoliberal metropolis as the coming of a social eden of diversity, energy and opportunity (ibid, p. 198).

This quotation emphasizes the way in which the activity of new in-groups (the 'urban renaissance'), along with the purported benefits to city and place, have taken centre stage not only in the policy arena, but also significantly in academic research on gentrification and revitalization (Shaw, 2008a). Accordingly, this has left a void in the analysis of displacement and estrangement of original residents as a primary concern. Old urban neighbourhoods are being re-colonized by mobile groups and new sources of capital as a new urbanism takes hold and slowly ushers out the poor and working-class while gentrifying an urban history. 


\section{The New Urban Village}

In a scathing critique of urban design, Sorkin (2007) asserts that New Urbanism is chiefly a solution for the altered spatial preferences of well-to-do suburbanites. A relationship between gentrification and New Urbanism can be seen in an early form within London's inner-residential districts during the 1960's (Moran, 2007). Though the New Urbanist movement had not yet been conceived, its redress of the suburban character but continued embrace of its socioeconomic values marks a sentiment similar to that of London's pioneering gentrifiers.

Contained in the idea of being part of the city and close to its amenities, but unattached to its social ills (ibid), remains the suburban ideal of class separation and privilege. By accommodating both new spatial and old class-based features, a different type of urban village is made possible, one that is characterized by social exclusion.

Citing the "postwar decline" of the old urban village, Zukin (2010, p. 109) accounts an instance of change in New York's East Village neighbourhood:

...residents socialized differently in the past... The number of residents has increased by about 12 percent since 1980, but more important, today there are fewer of the very old and the very young. "It was a working class neighbourhood", Joe says, "so everybody got up in the morning and went to work...And then, at 5 or 6 o'clock, everybody came home. And there was a lot of activity, especially in the summertime, when the weather was nice. People would bring chairs and sit outside, talk to their neighbours. Kids would play in the street...It was more of a social scene on the street" - very much an urban village. Today the block's rhythm is set by stores instead of families.

$\$ 5$

The last sentence reflects the pervading influence of consumer and destination culture on once

distinct urban neighbourhoods. If authenticity is now at a premium for consumption, then it is only a matter of time before all of these neighbourhoods undergo transformation as a result of increasing middle-class pursuit of urban affordability, and the associated new investment by government and the private sector. The balance between the old urban villages and the new corporate city appears to be tilting irrevocably towards the latter. Toronto has witnessed recent expanded commercial and residential gentrification in areas progressively further from the core 
such as Parkdale (Slater, 2004), Brockton Village, and South Riverdale (Walks \& August, 2008). In the inner-city sites of early long-standing gentrification, renewal once paved the way for destruction of the working-class urban village by re-housing the poor in tower blocks in the inception of the modern housing project. This freed up space for the production of the new form of urban village, which could be appropriated by a more advantaged class that had not previously practiced the pattern of active village/street life belonging to the working class (Raban, 1974). Ironically, working-class life and community would eventually become too much of a commodity for the working-class to afford in that gentrification drives up demand for the required urban spaces (ibid).

The new urban village is not the same functional and organic system; but the object of the mobile upper-middle class desire, and the target of the capitalist appetite. The neo-liberal preference is for a makeover of the traditional working-class urban village into a higher level profit-generating landscape. Parts of the city and population that practice a social life in public space (or 'public realm as lounge'), having less disposable income, are the antithesis of gentrification and renewal efforts that thrive on money spent at private institutions for leisure and entertainment. The traditional localized lifestyle of the working class (in many cases older immigrant groups) seems to be outmoded due to modest spending habits and less ability for revenue contribution (Zukin, 2010). The failure of these villages to embrace and mesh with the changing cultural and economic conditions around them has contributed to perceptions of financially inefficiency and potential for growth. One form of change has come at the intersection of postmodernism with the neo-liberal agenda, promoting the diversification and decentralization of mainstream capitalist reach towards a greater flexibility of options for accumulation (Harvey, 1989). The postmodern and post-industrial economy has thus helped produce and standardize new cultural frontiers in environments that were once too gritty or otherwise undesirable (Zukin, 1995). 
It is to be expected that the expansive domain of surplus capital in the neo-liberal city will target economically under-utilized space, specifically if it is in a relatively central, prospectively valuable location of a largely built-out city. In Toronto, the thrust of reurbanization may be perceived as hindered by unproductive landscapes and public institutions, notably Regent Park in the east portion of downtown, and the Centre for Addiction and Mental Health (CAMH) to the west of. 


\section{Postmodernism, Social Mixing, and the CAMH Redevelopment}

The decision to intersperse Regent Park's public housing stock with market units warrants critical examination through the lens of spatial justice and neo-liberal restructuring.

Recognizing the stated goals of benevolence for the recent redevelopment (de-concentration of poverty, social integration, neighbourhood investment) there is still reason to suspect the presence of less explicit motives involved. Given its status as somewhat of an economic deadzone on the map, and its central location, it would seem timely that the interests of profitbased renewal are now moving in. The Regent Park redevelopment is not an immediate focus of this paper, but it represents a strong parallel to the $\mathrm{CAMH}$ redevelopment, with similar agendas put forth as undermining both initiatives. The case of CAMH was selected for three reasons: It is likely the lesser known and less scrutinized of the two redevelopments; it represents a unique and unfamiliar intersection with planning and critical theory; and its location-west of the downtown core-is in line with the processes of geographically expanded gentrification proposed by this paper. As Davidson (2008) points out, the nature of the word 'gentrification' (gentry) refers to an essentially class-based change, and one that is not necessarily tied to just housing stock. With this in mind, the CAMH redevelopment, predicated on transformation of institutional and neighbourhood dynamics through the fusion of different social experiences, makes for a good example of how the gentrification or revitalization agenda need not involve a housing focus.

Between 2002 and 2008, CAMH was busy preparing its Master Plan and Vision for the third iteration of the site at 999 Queen Street West (now known as 1001 Queen Street West) (CAMH,2002;2008). The redevelopment looks to rectify the mistakes of past phases of addiction and mental health treatment through a postmodern renovation that looks to counteract modernist prescriptions of separation and highly structured authority. The new approach is founded on patient empowerment through the 'clubhouse model' of treatment in which 
authority is fragmented as 'members' (rather than patients) take more responsibility for treatment that comes on a voluntary bases; and a corresponding built form layout that opens up the facilities to the neighbourhood. Front and centre in the plan is the inclusion of the site in the neighbourhood's transformation into an "integrated urban village" (CAMH, 2008). A major tenet of this urban village is the mixed-use environment, into which CAMH facilities, staff, and patients are to be incorporated through unification of neighbourhood and institution. As we will see, there are inherent flaws in this premise, and faith in the deterministic relationship between a changing built environment and a desired change in behaviour remains. Similar to the Regent Park redevelopment, planning for the rehabilitation of a stigmatized group is tied to this principle. The critique of this redevelopment will also aim to exemplify it as being part and parcel to an inner-city reclamation project anchored by a middle-class agenda (Horowitz \& Schachar, 2010).

For CAMH, the urban village model is basically a re-articulation of New Urbanism in the context of institutional redevelopment (ibid). The 'integrationist urban village' is interpreted here as an overarching concept that exhibits qualities of both postmodernism and 'social mixing' theory in its appeals to the social engineering of inclusion and de-segregation. However, a neo-liberal undertone is detected, as prospects for increased revenue generation and capitalist advance in new territory are ingrained in these features and the vision for redevelopment. The influence of postmodernism adds another element, underscoring an appeal to the middle-class penchant for difference in pursuit of urban authenticity.

The Master Vision, heavily grounded in rhetoric of the New Urbanist form of the urban village, operationalizes its principles: an integrated network of public streets, public and private open spaces, a series of cohesive and transparent development blocks and most fundamentally, an integrated mix of CAMH, and non-CAMH land uses (CAMH, 2008). The Master Vision asserts that integration provides an opportunity for CAMH to participate in the ongoing revitalization 
of the Queen West neighbourhood while remedying decades of stigma associated with the site's former architecture and identity at "999 Queen West", and mental illness at-large (ibid).

\subsection{More Determinism at the Junction of Planning and Mental Health}

The current redevelopment reflects a dual shift in postmodernism's influence on the prevailing approaches to mental health treatment and urban planning; yet the thinking behind the proposed revamp of the Queen Street site is not all that progressive. The contemporary planner's commitment to the social integration aspect of the urban village construct strongly parallels the mid-century (modernist) planner's unfounded faith in environmental determinism through urban renewal. One must also question how planners justify the rapid adoption of this new belief in the healing power of integration given that the outcomes of its audition in Regent Park have yet to be seen (Horowitz \& Schachar, 2010).

The dogmatic pursuit of the idealized urban village model speaks to the haste with which planners (specifically those involved with CAMH and Regent Park) have bridged theory and practice. Here the practicing planner may be informed by theories that have not yet advanced past conjecture. It would seem then that the theory/practice gap that Allmendinger (2002) bemoans for being "de rigueur" in theoretical discourse may not in fact be wide enough. The CAMH (and Regent Park) redevelopment exemplifies the sentiment in planning that the new will inherently breed positive change simply by virtue of its divergence from and opposition to the failed previous model, in this case one built on separation and containment. In an unabashed attempt to fulfil a postmodern disposition, the redevelopment has totally subscribed itself to a policy of newness via social integration, and equates progress with an intended departure from outmoded modernist principles.

CAMH is targeted as being a stigmatized deterrent not only for social inclusion, but to neighbourhood investment and higher order capitalist aspirations. By integrating CAMH into 
the landscape of consumption, and injecting the commercial landscape into the CAMH site, a more viable investment environment is achieved in a frequently ill-reputed terrain and an increasingly competitive urban arena.

\subsection{Integration as Therapeutic Capitalism}

To assume a Marxist posture, the role of planning in the CAMH redevelopment was to justify the legitimacy and value of the urban village model while rationalizing the convenient intersection of capitalism and mental health treatment. In Toronto, a city that is 98 percent developed (Horowitz \& Schachar, 2010), progress has now set its sights on the potential of this 'under-performing' land.

It is revealing to note the absence of CAMH uses being incorporated into the site's surrounding neighbourhood; rather it is businesses that have worked their way into the facility's grounds. The functioning of the site is still contained (though not physically), but the introduction of non-CAMH uses enables profitability on formerly fruitless landscape. The employment of patients fulfills an appeal to pluralism and inclusiveness, but again helps to rationalize the expansion of commerce into this uncharted realm.

The Master Vision (2008) operates under the contention that the integration and inclusion of marginalized groups (those with psychiatric disorders or the poor) is an antidote to the social decay associated with the more modernist method of clinical containment and segregation. The Vision's Executive Summary (2003, p. 5) states,

Casual mixing between staff, clients/patients and visitors of CAMH with the surrounding community will occur naturally on public sidewalks, parks, shared community facilities and the cafes, restaurants and shops that will occupy the street level of buildings. CAMH uses will be integrated with other uses to create a safe, comfortable and welcoming place where the stigma of the institution can disappear into the rhythm of normal daily activities associated with city living.

Randolph and Wood (2003) note a decided lack of evidence to corroborate claims of the supposed trickle-down benefits of 'social mixing' schemes. Furthermore, the majority of 
research that does assess its value regards the theory as it applies to public housing projects, not mental health facilities (Atkinson and Kintrea, 2000). In the above passage, participation in mainstream urban life is professed to bring about desired behavioural outcomes. The mental health field - with the help of urban planners-looks to moralize the consumptive behaviours inherent in the dominant culture. The same speculative theory of 'integrational determinism' was employed by planners in the Regent Park redevelopment whereby a group of marginalized and stigmatized people-the urban poor-are to be absorbed into mainstream society in hopes of having a normalizing effect on their sensibilities; in other words, imposing on them to identify with middle-class values. In achieving this, fewer resources need be devoted to investing exclusively in the poor, and an even greater proportion can be put towards the real priority; the economic growth and upgrading urban land-use. 


\section{The Illusions of Mixed-income Redevelopment}

One must wonder if improving the lot of poor and excluded groups is really the chief goal of integrationist and socially-mixed redevelopment initiatives. While residential projects may claim minimal displacement, this is not sufficient or exhaustive of possible adverse impacts. The success of a social-mixing approach ought to be determined by a reduction of poverty and inequality among the original residents, not by neighbourhood upgrading or low direct displacement (Davidson, 2008).

Shaw (2008a) states that while direct and instantaneous displacement may not be observable, other types exist in the form of 'exclusionary (economic) displacement', and through the loss of community and neighbourhood resources. The former, a term coined by Peter Marcuse, accounts for future residents that may have otherwise moved in, who rely on the already declining availability of low-income housing stock, and for whom these neighbourhoods become off-limits due to diminishing affordability (Newman and Wyly, 2006). Community displacement occurs when newcomers seek to create a new sense of place contrary to established residents trying to protect their own, and impinging on their right to inhabit and maintain the spaces they depend on (Davidson, 2008). Incomers have the potential to influence changes to the neighbourhood including the redefinition of local politics and priorities for service provision (ibid). The result may be a loss of low-income resources (businesses, social space, public institutions) as new tastes are defined, and shifts in the desired orientation of services occur (Slater, 2006). Displacement of low-end commercial tenants takes place when businesses able to pay higher rents and catering to a higher-income demographic become interested in the neighbourhood following residential gentrification (Davidson, 2008). In a climate of neo-liberal accountability for public expenditure, a scaling back of public services is more likely to occur as demands change (ibid). In some cases reinvestment may benefit the neighbourhood as a whole (structural renewal, expanded private sector services), 
but often many of the upgrades suit the new, middle-class residents. A more complete definition and explanation of displacement is one avenue for demonstrating how the introduction of the middle-class to revitalize underserved neighbourhoods is not essentially a pursuit of social equity. It may in actuality be just another form of gentrification supporting a socio-spatial restructuring that threatens to reduce, if not totally deny, the claim of the poor to urban property and space.

The creation of mixed-income communities such as Regent Park in Toronto, or False Creek in Vancouver (Lees \& Ley, 2008) may be well-intentioned in efforts to socially integrate and counteract years of isolation from the city, but this strategy only compounds concerns about the decreasing stock of housing and space for low-income groups. The precedents and future plans (Lawrence Heights and Alexandra Park are two neighbourhoods being eyed for renewal) of mixed-income redevelopment in Toronto have not seen an expansion of public and affordable housing as much as the encroachment of middle-class housing into poor parts of the city. Mixed-income redevelopment does nothing to address the socio-economic exclusion in more well off neighbourhoods, avoiding the larger problem by using language of social change (revitalization, reinvestment, integration, inclusion) that is applied only to areas where the poor are concentrated. There is certainly no intervention here regarding the continued production of urban space for the predominant economic, cultural, and political interests. It is nothing new that the agenda of private sector investment is making markets and not helping the poor (Zukin, 2010), and its partnership in the redevelopment of public housing is no exception.

In its Department of Housing and Urban Development (HUD), the U.S. has also promoted the use of social mixing in redevelopment, in this case through the adoption of 'state-led gentrification' strategies (Lees \& Ley, 2008). Claiming a "win-win outcome for all political persuasions", one American legal scholar stated the following: 
While gentrification is associated with 'outsiders' invading a community, the proposed plan encourages the influx of homeowners who are not so different from the existing residents, thus allowing for a smoother transition. Even if some existing residents are displaced, by combining the literature on concentrated poverty with that on gentrification, we see that dispersing and integrating the poor is precisely what is called for. For the existing tenants who are displaced, so long as localities can prevent them from re-segregating in other blighted neighbourhoods, their living conditions will improve. The result will be neighbourhoods that are more stable and communities whose members will be better positioned to participate in mainstream society. This model is characteristic of what we could term 'third-way gentrification'-a gentrification where liberal and conservative interests converge. For liberals, the poor are better able to develop attitudes and expectations that will allow them to participate in mainstream society. For consenvatives, the poor become less reliant on public support and better able to provide for themselves (ibid, p.2382).

This quote elucidates the dangers of simplified and conjectural discourse on the benign effects of gentrification and social mixing (Shaw, 2008), specifically in its influence on policy. There are several ambiguous, if not objectionable points. Firstly, the speaker seems to rationalize displacement by assuming that living situations will somehow improve as a result. How the locality will "prevent them [the displaced] from re-segregating in other blighted neighbourhoods" remains a mystery. Also contained here is the naïve implication that the displaced will have no trouble finding adequate, low-cost housing elsewhere. There is no mention of the need to provide additional affordable housing options. Worse is the deduction that dispersing or splitting up the poor, and adding a dose of mainstream society, is a sure-fire recipe for stable communities and improved living conditions. It then goes on to assume that through contact with mainstream society (which they are further stigmatized as not being part of) the poor will inevitably develop the necessary traits for successful participation in it. The presence of a moralizing value judgement in integration initiatives is obvious-in this case to the point of being offensive-as if mingling with higher income brackets is a panacea for a pathologized condition of poverty. The redevelopment of poor and working-class neighbourhoods tends to take for granted a desire for middle-class standards (Gans, 1982), something that is embodied to its fullest in social mixing/integration approaches. 
The work of Robson and Butler (2001) has examined the relations between different social and ethnic groups in the Brixton neighbourhood of London. The metaphor of 'social tectonics' refers to the "parallel rather than integrative nature" of groups or 'plates', which overlap but do not really share the same social and cultural institutions (ibid). There is diversity in principle, but separate lives in practice (Slater, 2004). The alleged 'trickle-down' benefits of social and economic mixing have been too frivolously embraced, and utilized as a justification for breaking up low-income urban populations instead of investing in them.

The real issue is not solely that the poor are concentrated and need to be dispersed, but that certain areas have been too often neglected from public investment and consciousness. Displacing or dispersing residents only burdens them to find other, increasingly scarce affordable residence in the city. Whether or not its intents are deliberately sinister cannot be concluded, but mixed-income redevelopment is at least a de facto tool of neo-liberal restructuring in its partial privatization of a once totally public domain (Slater, 2006). The difficulty is that areas of concentrated poverty cannot seem to get substantial public sector investment independent of the need to involve the private sector and higher socio-economic stratum. If this could be achieved, such neighbourhoods would be less a problem for those living there, though likely still unfavourable to corporate interests. One reason that social mixing is not advocated in affluent or middle-class neighbourhoods is because the conditions and populace for acceptable levels of consumption and tax increment already exist. 


\section{Situating Policy in the Re-urbanization}

The role of state and politics is not traditionally involved in explanations of what drives gentrification, which tend to be dominated by a ritualized debate between economic capital and cultural dynamics (Wacquant, 2008). Lees and Ley (2008) recognize the under-emphasis, calling public policy the 'third driver' (beyond culture and capital) of so-called positive gentrification, with the state as a primary producer of the necessary space. Wacquant (2008) goes on to say that the structuring of the socio-spatial environment and its inequalities is steered politically and by the leanings of urban planning. Policy can affect trends related to housing patterns, the real estate market, and public space. The notion that gentrification has become central to government policy in Europe and North America, and increasingly in cities world-wide (ibid), does not bode well for ambitions of spatial justice. Part of the changing character of gentrification is associated with its representation in policy and planning practice, whether in the form of redevelopment or a Business Improvement Area (BIA). In the Parkdale neighbourhood of Toronto, housing policies and zoning by-laws have made finding accommodations more difficult for low-income residents and incomers (Slater, 2004). This example will be discussed further in chapter 9.

Wacquant (2008) argues that the state's role has become too concerned with economic growth as a whole, and less so with the stability of vulnerable populations. It is low-income communities that are most dependent on the state, yet economic interests favour the rich and middle classes. Part of the problem is that neo-liberal landscaping and too narrowly conceived ideals of progress assume aspirations of middle-class standards to be sufficient (ibid). The security of low-income residents and the social sustainability of cities is not an established priority. A growing influence of private sector interests in urban planning and development is partly suggestive of the point that political control is more 'up for grabs' in the neo-liberal environment (Davidson, 2008). The role of neo-liberal local governance has included promoting 
economic goals akin to achieving status as a global city; and has also meant greater similarities in policy across borders (Shaw, 2008b). The emerging global pattern of policy driving gentrification is evident in a range of cities, reaching places such as Cape Town, Auckland, and Mumbai (ibid). The spread of policy as gentrification has seen converging experiences of large cities in the global north and south; and has meant that the growth of globally competitive economies may overshadow the interests of the poor and local redistributive policies (ibid).

The shifting function of policy now serves to encourage gentrification in the form of revitalization. Once regarded as a 'dirty word' with strong class connotations, gentrification has undergone a transition whereby its meaning became more ambiguous, and eventually started to comprise positive neighbourhood changes. What Ganz (1982) identified as the private version of urban renewal is no longer strictly a private process. The term revitalization-often part of the language of renewal-presumably refers to healthier property values and tax revenue, and not to the replacement of the poor by the more economically-active, as in gentrification (ibid).

Urban design and planning tools can be guided by the principles of neo-liberal economics, and sometimes contribute to market-based investment inequalities and exclusion (Sorkin, 2007). The city 'bonusing' system and Business Improvement District (BID, an American form of the BIA) are viewed as particularly problematic. BIDs in New York City have tended to favour large businesses/property owners and chain stores at the expense of those providing for the needs of the poor (Zukin, 2010). In Harlem, the use of BIDs and Empowerment Zone (EZs provide economic incentives for businesses in low-investment areas) represent public investment in the private sector, and have resulted in significant commercial displacement (ibid). The EZ took on the task of 'making markets', courting chain retailers to satisfy recent middle-class settlers and attract new ones (ibid). These practices create demand for new housing reminiscent of what Lefebvre (1974) identified as the 'reproduction of the social and 
economic relations of production'. Here he is referring to the way that social and economic processes produce new spaces for consumption by different groups.

The zoning changes carried out during the 1990 s and 2000 s by the New York City Planning Commission were used in conflicting ways to forward the agenda of gentrification and neighbourhood up-scaling. On the one hand, height and density limitations were used to preserve the brownstones and low-rise character that attracted gentrifiers; on the other, the rezoning of $125^{\text {th }}$ street in Harlem (popularly known as the 'Main Street of Black America') gave developers the right to build higher in exchange for renting storefront space to 'cultural facilities' (Zukin, 2010). These facilities were not specifically defined, and were inclusive to large chain businesses (ibid). The plans were approved despite protest from residents and Harlem's city council representatives for more affordable apartments, echoing the fear that Harlem was excluding its original residents and business owners, and beginning to betray its cultural legacy (ibid).

The growing reliance and affinity for public-private partnerships has changed the pursuit of the public interest, and facilitated private economic activity in publicly initiated projects (Sorkin, 2007). The bonus system can compromise good planning in favour of public amenities, which along with a rise in property values or neighbourhood improvements may be seen as a greater good; but whether they actually benefit the intended community and not just newer residents is unclear (ibid). The fundamental problem is that rather than opposing unfit developments outright (and advocating for communities to maintain their neighbourhood), city governments may opt for concessions from developers to theoretically negate negative impacts. Tools such as the BID, EZ, and bonus system can be effectively utilized as part of the neo-liberal apparatus, ensuring prosperity at the top, but also massive gaps of income and housing (ibid). 
Favour is often given to new development that can demonstrate environmental sustainability or preserve heritage aesthetics, both of which attract certain interest and have high market value (Zukin, 2010). They both contribute to a precious commodity sought by those with the mobility and capital to displace working-class populations unless protections are put in place. Building conversions and adaptive re-use for housing are at an especially high premium. In Toronto's West Don Lands, development has been criticized for failing to incorporate an agenda of social justice/sustainability in its focus on environmental standards and structural conversions (Bunce, 2009). The process has paid little attention to the needs of nearby communities (affordable housing, employment) and has been characterized as indirect, government-led gentrification (ibid).

Two other Toronto neighbourhoods, Brockton Village and South Riverdale (near the West Don Lands), had until recently resisted gentrification almost entirely but-partly as a result of changes in local government policy and the housing market-they have now succumbed to the first stages (Walks \& August, 2008). The most influential changes affecting such neighbourhoods of expanded gentrification occurred in the mid 1990's at the hands of Ontario's aggressively neo-liberal Conservative government and include: a shift away from 1) alternatives to urban renewal that favour local participation and self-determination and 2) the protection and acquisition of low-income housing by the City; the reconstruction of rent control policies to allow charging whatever the market would bear for vacated units (this resulted in exclusion of many low-income tenants); and limits on the conversion of housing into rooming houses, bachelorettes, and secondary suites (reduced affordable housing stock and increased homelessness) (ibid). The ironically named 'Tenant Protection Act' of 1998 introduced vacancy decontrol, which effectively eliminated rent controls on vacant units once they become available through natural turnover (Slater, 2004). Landlords can then charge whatever they can get; supporting the impetus to get rid of poor tenants through substantial 
rent increases and unit improvements (ibid). In general, there has been decreased government protection of low-income and non-market housing, and a reluctance to intervene in exclusionary market processes that in some cases are supported.

The potential of policy to create more equitable cities is often not realized due to the lack of political will to intervene (Shaw, 2008b). Depending on the context, there may also be inadequate state mechanisms to manage the unjust effects of gentrification (Davidson, 2008). Current policy does not afford people the right to define and maintain their own urban space, and communities have little formal recourse in reacting to injustices (ibid). As a whole, the substance of theory on gentrification may need to become more amenable to policy and policymakers (Shaw, 2008b). 


\section{Parkdale, Housing, and Social Regulation}

Parkdale is a neighbourhood west of downtown Toronto. Its history of socio-economic change has involved urban renewal and more recently municipally-managed gentrification, both of which used justifications aided by the use of 'slum rhetoric' and various social constructions (Slater, 2004; Slater \& Whitzman, 2006). The period of urban renewal in South Parkdale that brought high-rises for the poor in the 1960 s was preceded by neighbourhood disinvestment associated with the construction of the Gardiner expressway. (Slater, 2004). Also relevant was the de-institutionalization of Toronto psychiatric facilities in the 1970s and 80s, which released patients into the area, resulting in an abundance of rooming houses and bachelorettes in response to low-cost housing needs (ibid). In the mid-1980s, periodic gentrification began and has since intensified (ibid). Bachelorettes (self-contained, single-room occupancy with bath and cooking facilities) and rooming houses represent the cheapest form of permanent rental housing in Toronto and a vital resource for the city's poor and marginalized; but zoning and by-law restrictions, the de-regulated rental market, and 'nimbyism' from the homeowners association have caused a decline in these dwellings that has been linked to increased homelessness in the city (ibid).

Moral regulation can exist as a process carried out by governments. It may start when a neighbourhood is labelled as a slum, assumed unfit to live in, and appearing as an eyesore that deters investment (Glasbeek, 2006). Such areas may be neglected, under-serviced, or lacking amenities, but still performing necessary functions for specific demographics. In the case of Parkdale, this function was supplying housing to a vulnerable population whose concentration and living conditions appeared undesirable to municipal government and property speculators. Here it is not just sub-standard housing that is the concern, but also a population that is stigmatized and targeted for dispersal by housing policy. The use of cultural rhetoric and social fragmentation techniques are not unique to the context of Parkdale. 
Leading up to its redevelopment in the 1950 s, Boston's west end had been labelled as a slum by the media, housing authority, and wealthy Bostonians who didn't live there (Gans, 1982). Smith (1996) uses the example of New York's Lower East Side, described by the media and government agencies as 'devoid of meaning and identity'; trivializing its working-class history and geography to create a new settlement frontier. Similarly, Boston's west end was judged by a superficial outsider gaze. Regarded by some as a "vice-ridden set of hovels", and ignorant to the reality that residents overwhelmingly reported that they liked living there, and that the pros (location, low cost of living, tight-knit community) outweighed the cons (some transients/deviants, old and sometimes deficient housing) (ibid). A stable, dense, low-rent district should not be conflated with a slum. The image and definition of a slum can be a matter of social construction, owing to different class and cultural standards or biases. Behaviour that appears culturally different or even deviant is not necessarily harmful or antisocial. Gans (1982) emphasizes the need to protect a 'right to choose', whereby one can opt for low-rent urban districts in acceptance of the associated imperfections of housing and neighbourhood.

The depiction of parts of Parkdale as a slum and a related narrative of urban decline appeared in the media, real estate publications, and the language of municipal policy (Slater $\&$ Whitzman, 2006). Whether to the end of urban renewal or attracting middle-class families and home ownership, socially/politically constructed conditions can be used towards capital reinvestment and ultimately displacement. The language of local government, newspapers, and pressure groups (which once included the short-lived Ku Klux Klan of Canada) condemned the social impacts of multi-unit housing, and an immigrant reception function that amounted to 'invasion by foreigners', as a threat to the nuclear family (ibid). Toronto Star articles of the 1970 s and 80 s refer to 'the once "leafy" streets and "jewel"-like homes becoming a "dumping ground for the poor"' (June 16, 1982)...'and the older houses "cut up into bachelorettes" for "two-legged rats" who "sleep all day and roam the streets at night"' (April 5, 1979)..."an 
unbearable hell not fit for decent people" (Sept. 14, 1980) (ibid). As early as the 1910s, when Parkdale was at its wealthiest, the neighbourhood was called a slum (ibid). But it was the resurrection of this moral panic in the 1970 s that began a series of reactions against Parkdale's disproportionate share of rooming houses and its marginalized residents. A moratorium on new housing conversions passed in 1978 in accordance with the already restrictive zoning practices found in much of the central city (Rosedale, the Annex, Don Vale) (Slater, 2004). Frequent attempts to regulate housing diversity, including a by-law prohibiting 'for rent' signs, proved unsuccessful. In 1996 the City initiated an area study that would see to the closure of some rooming houses; and passed an interim control by-law that made any new bachelorette/rooming house development or conversion in South Parkdale illegal (ibid). In the City's subsequent revitalization proposals, the "de-housed tenants" were to be re-located, though the question of where was not addressed (ibid). Examination of the documents reveals that the compact presence of low-income single persons in small dwellings was seen as the areas primary social problem (Slater \& Whitzman, 2006). The view that a spatial concentration of low-income singles is unhealthy is full of prescriptive moral regulation. If this is the neighbourhood's disease, then the introduction of middle-class families is the remedy (ibid). The moratorium on rooming houses and lot limitations of 1 or 2 units amounts to the displacement of poor singles and little more than an attempt at social cleansing (ibid).

The municipal approach to sub-standard housing in Parkdale has favoured restrictive policy and zoning, leaving issues to do with 'slumlords' and poor maintenance only partially and indirectly addressed, or not at all in the case of many high-rise units (Slater, 2004). Over 10,000 units of mostly private-sector high-rises in Parkdale are considered affordable but in critical need of major repairs (Slater, 2004). The living conditions of the majority of Parkdale residents have received less attention from the City than the issue of restoring stable, singlefamily home ownership for a comparably small population, in houses that had never seen 
single-family occupancy until the last ten years (ibid). The increase in gentrification since the 1980s has brought more neighbourhood polarization between owners and low-income/social housing renters (Slater \& Whitzman, 2006).

The use of labels like 'ghetto' and 'slum' deem an area ready for revitalization, questioning the social balance and paving the way for discriminatory housing policy and gentrification (Slater, 2004). While some of its mansions did once comprise single-family ownership, this was only one aspect of the neighbourhood and its history. Nostalgia for Parkdale's mythical former status as a uniformly upper-middle class urban village is tempered by its longstanding reality as a low-income rental haven for single men and women, as solidified by earlier disinvestment and abandonment. A critical understanding of Parkdale's housing context fits in with what Sandercock (2003) has called the "noir side" of planning history, which identifies an alternate narrative of opposition to difference. For Parkdale, the alternative historical record reflects over 100 years of persistent housing diversity in the face of opposition, and could easily justify a different approach to municipal policy that aims to recognize and strengthen the continuity of inexpensive rental options (Slater \& Whitzman, 2006). A shift in policy would require going beyond accepted cycles of investment, disinvestment, and reinvestment to promote a variety of housing options towards a more socially sustainable city (ibid). 


\section{Containment of the Urban Poor}

In her research on planning and indigenous cultures, Leonie Sandercock (2004) questions the notion that planning practice is truly 'post-colonial'. She uses the example of Aboriginals in Canada and the US being dispossessed, and excluded from land-use decisions through political power relations, in which planning has often been complicit (ibid). Like Sandercock, Yiftachel (1998) recognizes the 'dark side' of planning. For him it is a latent control function that challenges the general assumption of planners as 'benevolent do-gooders' and reformers. Planning should be understood not as state intervention, but as an arm and creation of the state that diffuses dominant interests through socio-spatial practices fostering inequality (ibid). The spatial oppression of Aboriginals is analogous to that of many under-represented, lowerclass urban groups adversely affected by a 'neo-colonial' mentality (Sandercock, 2004). Through structuring of the housing market and re-distributional mechanisms, groups without the requisite capital for mobility can be controlled and contained by policy and market forces. The low-income and working-class populations that once occupied large portions of the city have been neatly contained by urban renewal, and gentrification continues to re-colonize $] \uparrow$ neighbourhoods and confine old residents to shrinking spaces and the urban fringes.

Countless examples of redevelopment and urban renewal have sought to clear away old poor or working-class neighbourhoods and condense them into modernist high-rises. These areas often consist of small, unattractive housing and are considered slums. By minimizing the lot of the poor and relegating them to high-density towers, the perceived blight on the streets is reduced, re-producing space for appropriation by new groups. This was the case for a large section of Toronto's Old Cabbagetown neighbourhood, located just east of downtown, which now houses Regent Park. The Trefann Court neighbourhood (to the south of Regent Park South) is one of two small remnants of Old Cabbagetown, having managed to stave off the aggressive renewal of the 1940s and 50s (Barc, 2011). During this craze for inner-city 
revitalization, the area then called Don Vale (now known as Cabbagetown) was also considered for demolition, but unlike Old Cabbagetown, it possessed the saving grace of a quaint Victorian charm that attracted middle-class interest (ibid). The modest houses and nonconforming street life of Old Cabbagetown's working-class, largely ethnic urban village contributed to its eventual razing. The land grab allowed for the modernist construction of more orderly structures that isolated and contained the poor, surrounding them with borders that prevented their communal life from spilling into the public streets. This last point is an A important one, as it is a requisite part of global city strategies to promote an attractive terrain of investment and consumption. 


\section{Disinvestment in Low-Income Resources}

Disinvestment in neighbourhoods can also be used as a tool of renewal and socio-spatial restructuring. An image of decay and blight is exacerbated by a lack of gradual investment and political attention that allows an environment to deteriorate, and vacant or marginal properties to build up in preparation for a 'cataclysmic' reinvestment by developers and municipal government once conditions are appropriate (Jacobs, 1961; Sharman, 2006). This may actually prevent or undermine regeneration from more local sources (ibid). The subsequent takeover of working-class districts by middle-classes can be branded as a collective good in the form of revitalization (Wacquant, 2008), but really the fragmentation of these once dense and unified pockets in cities leads to a decline in low to middle income neighbourhoods (Hulchanski, 2010). As capital marks some neighbourhoods as new 'frontiers of profitability', these areas are hyped for investment while others become more neglected and concentrated in disinvestment (Fainstein et al, 1992). It seems that neighbourhood investment is either boom or bust. A place may lack essential services (banks, grocery) but gets little until it is poised for large-scale redevelopment to suddenly counteract lengthy periods of decline. Lack of services and underinvestment ought to be addressed by steady government interventions and provisions; ] not by the market through real estate renewal, gentrification, and displacement.

Cultural and neo-liberal economic changes have occurred with "invisibility" to poor and working-class residents, as these groups' territories increasingly become the stigmatized "ethnic ghettos" or high-rise containment areas (Wacquant, 2008). It was only about 25 years ago that low-income families in Toronto could find housing in most parts of the city, and different income groups lived next door to one another (United Way, 2011). Today many of Toronto's low to middle income earners have become poor, and more likely to be concentrated in high poverty areas (ibid). Access to quality housing options in the global city is now more stratified and sharply divided not only by finances but by location. Manhattan is an extreme

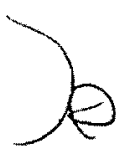


example where housing is almost entirely out of reach for all but the wealthiest of newcomers, with the middle classes occupying the suburbs, and the poor being "locked in the ghettos" (Fainstein et al, 1992).

Between 1997 and 2007, New York City lost 30\% of its subsidized apartment stock in favour of homogenized up-scaling (Zukin, 2010). Canada's production of new social housing fell from over 20,000 units a year in the 1970 s and 80 s to less than 200 units annually after 1995 (Walks, 2006). Policy has traditionally been more concerned with housing improvement (renewal, rehabilitation, revitalization) than supplying additional housing to the poor (Gans, 1982). This holds true for many cities today. Moreover, some government housing programs tend to identify the poor with the social needs and situations of the group above them in the socio-economic hierarchy (Fainstein et al, 1992). This permits an upward siphoning of funds earmarked for affordable housing whereby the real benefit may not be to the lowest income groups. By appealing to the subjective and flexible category of affordable housing, concern for the needs of marginal populations can be neutralized almost just through lip service (ibid). 


\section{Planning for Comfort-The Changing Fabric of the Public Realm}

Consequent to an adjustment of fiscal resources to favour corporate-defined redevelopment priorities is a decreasing 'right to the city' for the poor and homeless in the public and parochial realms of downtowns. The heightened regulation of these spaces is suggestive of a new direction for downtowns; ensuring middle-class consumption and recreation environments without too much exposure to diverse working-class and sub-cultural street life. New development is centrally clustered to promote a secure and attractive downtown image (Davis, 1990). The inner city is less a place of fear or trepidation than it used to be, but levels of difference and 'otherness' are suppressed by the street-level changes that accompany commercial redevelopment in prioritized consumer districts. Extreme practices of policing and ordering of urban space may be epitomized by American cities such as Los Angeles (ibid); but other cities are not impervious to the trends. Toronto is subject to its own measures for comfort and security in varying forms including Ontario's Safe Streets Act (1999) and the privatized Yonge and Dundas area redevelopment. The former outlawed 'squeegeeing' and "aggressive panhandling" (ibid), espousing the moral regulation function of government to determine what behaviours are acceptable where. The law criminalizes behaviours of the poor with sometimes vague wording and non-exhaustive definitions that leave room for inconsistent application. The latter exhibits a neo-liberal and entrepreneurial trend in planning that in this case used public money to serve largely private purposes (Filion, 2010). The creation of 'Dundas Square' introduced a space that was not inherently public or private, but at some intersection of the two. The programming in Dundas Square and the activity around it are devoted to enhanced revenue generation, with private security and police enforcing order and controlling undesirable behaviour (ibid).

In general, an influx of condos, inflated real estate, corporate chain stores, and a focus on urban design contribute to a restructuring that trades social and cultural diversity for looking 
good (Davis, 1990). The primacy of visuality and physical design measures in redevelopment and revitalization has served to promote the interests of the socially mobile, the experience of urban amenity (shopping, fine dining), and 'pleasantly manicured' spaces as playgrounds for the financially-able (Sorkin, 2007). This has come with little attention to the needs of the urban poor. For people without adequate housing or the conveniences available to higher income populations, the public realm is relied upon differently. The use of public spaces in unconventional ways has been restricted in numerous American cities by the criminalization of certain behaviours (sleeping, sitting, grooming) unique to the homeless in terms of where they take place (Mitchell, 1997). Montreal has enacted similar laws dictating what can be done where that amount to the 'conceptual shrinkage' of public space (Fortin, 2008). This creation of crimes reflects a changing political economy that privileges an aesthetically pleasing urban landscape over the diverse and alternative functioning of public space (ibid). New built form and commercial investment have the power to make populations that rely on fixed spaces vulnerable to displacement.

There is somewhat of a grey area that exists when drawing the line between public and commercial space (Gowan, 2009). The expanding reach of commercial character has contributed to what Gowan and Zukin (2010) refer to as "disneyfied" entertainment areas that compromise the value and diversity of the truly 'public city'. Shiny new spaces offer clean and predictable consumer environments and homogeneity of place that is not really urban at all. This is what John Hannigan calls "riskless risk" (ibid); providing for 'safe excitement' of the urban experience for a new demographic and inevitably excluding others. Market-based norms are now embedded in the public realm augmentations of many global cities and have expanded landscapes of social inequality (ibid). More broadly, increased police/security presence in the "proletarian public sphere" (streets, parks, bars) has sought to moderate alternatives to market relations and instil a regime of "bourgeois social order" that also entails a 
sanitized image (Gordon, 2006). Wacquant (2008) also discusses the city as site for bourgeois or middle-class consumption, with police and security providing behavioural cleansing to achieve the presence of desired demographics and the dislocation of others. The appearance of disorder and strong levels of difference are unacceptable. But the aspiration of cities and some planners for a defined urban order and harmony is misguided and derives from uneasiness about the sources of human and cultural diversity (Sennet, 1993). The idea of 'functional disorder' accepts conflict and disorder as inevitable, and even beneficial, in large cities (ibid). Efforts are wasted in trying to mould human behaviour with environmental and social structuring mechanisms. Displacement of unwanted people and activities will only lead to an increased presence elsewhere.

Similar to the way unfavourable social constructions of the old working-class urban villages are used to rationalize renewal and redevelopment; governments, police, and the private sector regulate unwanted behaviours of the poor and homeless in the public realm, also to the ends of revenue growth. An obsession with comfort and order has fundamentally changed the character of many inner-city neighbourhoods and public spaces to reflect shifting population dynamics breeding socio-economic exclusion. Along with the housing market and policy, changes to the public realm are contributing to the re-urbanization by optimizing conditions for profit and the unencumbered presence of the upper and middle classes. 


\section{How Can Planning Adapt?}

Among the factors that contribute to an ignorance of planning's 'dark side' is a close link between theory and practice, both of which may serve to promote the profession's mutually productive interests (Yiftachel, 1998). The solution would invoke a larger theory-practice gap, with theory operating at a greater distance in order to critically analyze the structures and consequences of practice, rather than being a prescriptive compliment (ibid). Yiftachel is convinced of the control function of planning - that its job is to maintain the status quoimpotent and unwilling to drive significant change. Sandercock (2003) acknowledges the 'noir', but also the capacity for reform. Despite its failures and criticism, the modernist planning project was not completely devoid of ideology or ethical underpinning. Its misguided attempts at remedying the living conditions of the inner-city poor were at least partly founded on good intentions and an idea of the public interest (however narrow it may be). Planning in the $21^{\text {st }}$ century must be careful not to disregard what is learned from modernism. It must proceed as a consciously ethical, goal-oriented, and political profession that seeks to address the social, cultural, and environmental justice issues of both modernism and postmodernism. Current problems are shaped by new and more powerful forces of economic and cultural change that require an understanding of "new planning literacies" and a communicative rationality (Sandercock, 1999). Narratives of progress and sustainability represent struggles at two competing scales: local community (the city of memory) versus the wider interests of change (the city of desire) (ibid).

Instrumental or 'means-end' rationality is no longer appropriate for most planning scenarios. Ignorance of the future is an inescapable problem, and the ability to anticipate the outcome of actions like redevelopment is quite limited. This should inform an approach that allows for flexibility and adaptation to changing conditions; not one that is rigid and stays a course until the downfall of its core principles. Devotion to a total plan that hinges on a single 
theory is not a logical strategy for resilience or mitigating unpredictability. The mistakes of planning will be realized down the road, and the best way to minimize the negative impacts is planning with a conscious recognition of this. This may mean a relative 'unfinishedness' that does not isolate a project from changes over time, and permits ongoing adjustments to new wisdom. This is the opposite of cure-all approaches that often subscribe to ephemeral best practices which-upon failure or obsolescence-may have negative impacts on the people affected or require costly overhaul and re-conception.

Generally accepted notions of 'good planning' may turn out to have adverse effects on certain groups. Planners and other actors must acknowledge the ways in which processes like gentrification and redevelopment may reflect broader economic or political interests and uneven societal power structures (Soja, 2010). The planner's knowledge and profession is a construct of power, and it must be reconstructed and redirected politically to pursue sociospatial equity in practice (Sandercock, 2003). De-industrialization has disproportionately affected the working poor (Soja, 2010). Spatial policy interventions are needed to combat market forces that exploit their community locales. Perhaps planning thought should begin preparing for and initiating measures for community autonomy such as a re-localization of production modes. Local government has the ability to limit redevelopment and conversion of employment lands to maintain areas of working-class employment and housing within the city (Walks \& August, 2008). In the case of manufacturing and industrial uses, an obvious challenge is posed by post-industrial decline, but the use of economic incentives and innovative planning strategies may help to reduce the loss of these businesses. 


\section{Intervention Experiences}

Many of the contradictions of the neo-liberal state are felt at the local level. Here the tensions require innovative modes of urban governance, and the negotiations of progressive reform by planners (Shaw, 2008b). While communities may not like the local impacts of publiclysanctioned private growth, the fact remains that a ready alternative has not been presented in the aftermath of municipal downloading and funding gaps (Fainstein et al, 1992). Before issues such as inadequate state production of social housing and low-rent market housing in the city can be fully addressed, a viable substitute for generating municipal revenue, or a more progressive arrangement of budget structures and funding relationships must be realized. With that said there are still supports and interventions that can occur through policy and planning at the local level.

Several ethnic communities have managed to remain entrenched in specific sections of Toronto's urban fabric for decades (Walks \& August, 2008). Among them are Chinese and Korean populations that maintain their culture and housing in areas that seem to change little relative to their surroundings. These communities are quite autonomous, often conducting business in the mother tongue, and using internal networks of social and economic capital (housing finance, information channels, labour) to retain control over part of the housing stock and commercial properties (ibid). Such communities need not be ethnic, just tight-knit, selfreliant, and self-organizing. This can be supported by policies and social services for cultural organizations that may also encourage customization of living environments and the use of non-market/non-profit sources of financing to limit gentrification (ibid). One way to protect neighbourhoods is by ensuring that land-use, housing and commercial stock is unattractive to middle-class gentrifiers. A policy of 'benign neglect' for grittier working-class urban areas has worked for impeding gentrification in Toronto's South Riverdale neighbourhood, where the continuance of harmless but undesirable industrial land uses ('nuisance uses') nearby has 
rendered the area less amenable to higher income brackets (ibid). This is reaffirmed in industrial inner-city neighbourhoods of Vancouver (Ley \& Dobson, 2008). Municipal government may wish to invest in such locales to generate greater economic activity, but in the current context, this only contributes further to the reduction of low-income housing stock in the city, something that cannot be ignored. A strategy in Vancouver has recognized the potential of even renewed social housing in a redevelopment to upgrade a landscape and entice private sector reinvestment and gentrification, and has thus promoted the use of a raw, non-aesthetic building style (ibid).

There are state mechanisms and policy that exist to allow for reinvestment in a disinvested neighbourhood without stimulating gentrification. The question is of political will and follow-through. In Copenhagen, Denmark a plan for urban renewal in the poverty-stricken Inner Vesterbro district was carried out with several conditions in place to prevent displacement, exclusion, and loss of low-income resources (Larsen \& Hansen, 2008). First off, initiatives were undertaken to address employment issues, and to coordinate and improve the social work of public and civil society groups (Shaw, 2008b). Stipulations were also put in place for established rent ceilings, dwellings made suitable for singles, youth, and the elderly, and a legislative right to permanent re-housing for residents uprooted by the process (ibid). A cooperative system facilitated by "favourable state-guaranteed loans" enabled tenants to acquire ownership of inexpensive housing (Larsen \& Hansen, 2008). The approach in Copenhagen was initially successful in preventing direct and indirect displacement, but some gentrification did occur eventually as a result of both public and private sector subversion, and lack of political follow-through (Shaw, 2008b). Even so, a precedent was set for the viability of similar interventions. A crucial pre-requisite was that evidence of the negative effects of gentrification and the reasons for needed market intervention had been established and accepted (ibid).

Vancouver has engaged in meaningful experimentation with policy recommendations for 
obstructing gentrification and displacement in its Downtown Eastside. Along with the removal of land from the market and state-subsidized social housing construction, the maintenance of industrial land and a 'public benefits tax' are identified as factors inhibiting gentrification (Shaw, 2008b). The public benefits tax entails the City releasing parcels from its property endowment (land bank) and requiring private developers to set aside $20 \%$ of each site for social housing (Ley \& Dobson, 2008). Perhaps more suited to the current climate may be the work of planners in collaboration with the private sector to permit very small apartment units (under 300 square feet) to ensure affordability (ibid).

Policy responses to gentrification in Vancouver have often been prompted by mobilization and political activism at the neighbourhood level (Ley \& Dobson, 2008). Through participation in local planning processes, anti-gentrification protests, and street demonstrations, the Downtown Eastside has been able to find sympathetic support from the wider community and government (ibid). Meanwhile, minor harassment of gentrifiers and an image of deep poverty (homelessness and a concentration of shelters), street crime, and visible drug-use (a safe injection site is located here) have deterred many realtors and developers from risking investment in an unstable and potentially dangerous market (ibid). With its close proximity to the central business district, waterfront views, abundance of heritage architecture, and slum characteristics (20-25:1 expenditure to revenue ratio), the Downtown Eastside would seem a prime candidate for renewal (ibid). Despite these risk-factors, it has managed to remain largely a representation of the "public city" with "a strong welfare state imprint, including a substantial social service infrastructure" (ibid). Protection of this has been successful partly because the neighbourhood is so politicized. Promoting the possibility of broader recognition and enhancement of poor neighbourhoods as meaningful communities-and not slums in need of renewal-is an essential step in establishing a right to the city.

The range of policy prescriptions discussed are not endorsed as universal in application, 
but would be particularly effective for globalizing cities with large and growing low-income and immigrant populations that are increasingly confined to less accessible and poorly serviced areas (Walks \& August, 2008). However, most municipal policy continues to run counter to the sentiment behind market intervention and the protection of affordable urban neighbourhoods (Shaw, 2008b).

Vancouver's recent mantra has been "revitalization without gentrification", which headlines a tri-level government strategy to address the Downtown Eastside's social problems with social mixing (Ley \& Dobson, 2008). Middle-class housing will be introduced on select available sites, and non-market units will replace the declining stock of single-room occupancy in order to maintain the level of affordable housing (ibid). While gentrification has not gone unchallenged by a hostile environment, it has since been slowly advancing (ibid). Nearby, a public-private partnership has spawned a mixed-income, mixed-tenure redevelopment that cleverly used the marketing slogan "Be bold or move to suburbia" (ibid) to help prospective residents overcome their apprehensions about the neighbourhood. There is a sense in the community that this 500 market and 200 social unit balance might be "as good it gets" in this neo-liberal era (ibid). 


\section{Conclusions}

The urban project has now engaged a mandate of 'trimming the fat' that involves the further marginalization of disadvantaged groups. Those who are unable to adapt to a changing urban economy and culture are left behind, as insufficient efforts to generate equity fall flat. The staggering growth of income inequalities is paralleled and compounded by a more discreet inaccessibility to important urban spaces and resources.

The big city was once a place that nurtured difference and embodied it spatially in a range of neighbourhood images and socio-economic climates. Various cultures and income groups could carve out a niche in the built environment. As urban space becomes more commodified, many neighbourhoods are being re-urbanized, in many cases as a result of their authentically urban pulse, as more advantaged demographics exercise their will, spatial mobility, and vast real estate domain. Displaced residents and poor immigrants are largely $r$ confined to new and less suitable areas of settlement in the periphery. These trends demand a greater social and "spatial consciousness" (Soja, 2010) on the part of urban planners, policymakers, and politicians to mobilize action that is receptive to this growing dimension of inequality. Local awareness and activism, and a more effective relationship between policy and academic discourse can be a precursor to a "spatially attuned democratic politics" (ibid) and the pursuit of socio-spatial justice. The belief that planning should be apolitical or value-neutral must be abandoned to allow for the inclusion of new positions and knowledge bases, and an ethical course of action to redress the cultural and economic inequities of cities.

In the current neo-liberal context, government power and motivations are intertwined with corporate interests and the private real estate market. The real value of public funds and projects must therefore be questioned (Harvey, 2008). The disparate consequences of global economic integration and cultural standardization are manifest spatially, politically, and in policy at the urban level. The role of planners is to either resist these forces or help to produce 
their manifestations (Sandercock, 2003). Ideally the planner's constituency would be first and foremost the economically and politically disadvantaged. Ideally they would advocate and participate in regulating the production of urban space for higher order populations and investment; but this onus has not been adequately accepted, nor have the mechanisms for doing so been adequately established. Given the altered socio-spatial expression of urban areas, the extension of urban services, amenities, and character to under-invested and underwhelmed suburban landscapes within the city is a logical directive. While suburban intensification is a recognized planning goal in many cities, public reinvestment has proved to be especially challenging in areas isolated by poverty and neglect. Any aspirations of more even and equitable development have yet to materialize, as there is still room for financially and spatially mobile populations to re-colonize desirable sections of the urban city. Until local rights and levels of resistance can be elevated and reinforced by politics and policy, this process will continue, and the globalized cities of the developed world will continue to be polarized and transformed by economic exclusion. 
Appendix 1.a)

\section{MAP 1: CHANGE IN AVERAGE INDIVIDUAL INCOME, CITY OF TORONTO, RELATIVE TO THE TORONTO CMA, 1970-2005}

Average individual income from all sources, 15 years and over, census tracts

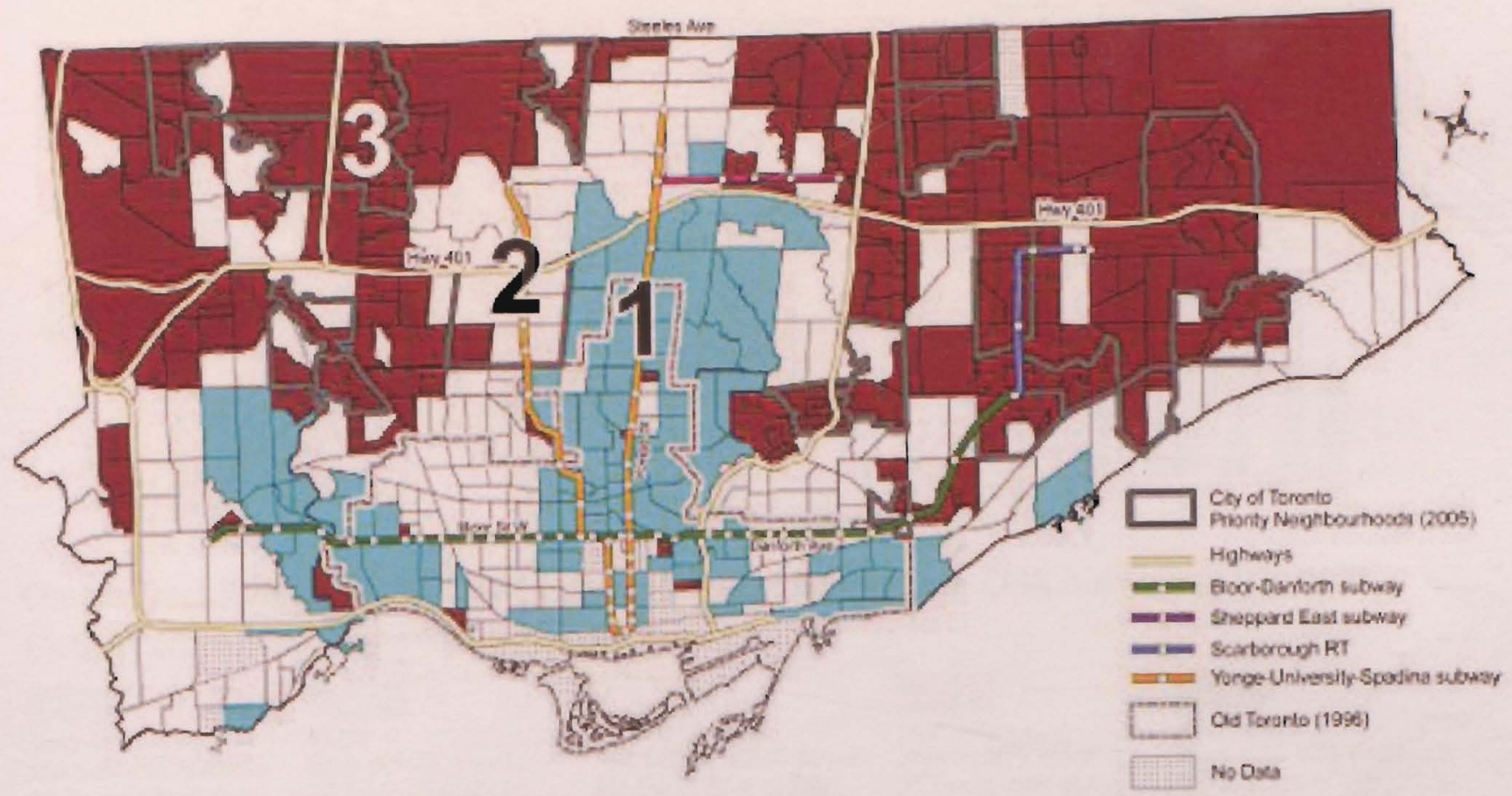

Change in the Census Tract Average Individual Inceme as a Percentage of the Toronto CMA Average, 1970-2005

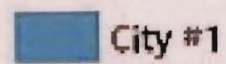

Increase of $20 \%$ or hore 100 Census Trocts. $20 \%$ of Cily

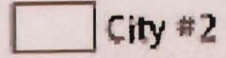

Increase or Decrease

is Less than $20 \%$

208 Cenus Trocts $40 \%$ of City

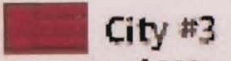

Decrease of $20 \%$ or More 205 Census Troess, 40\% of city 
Appendix 1.b)

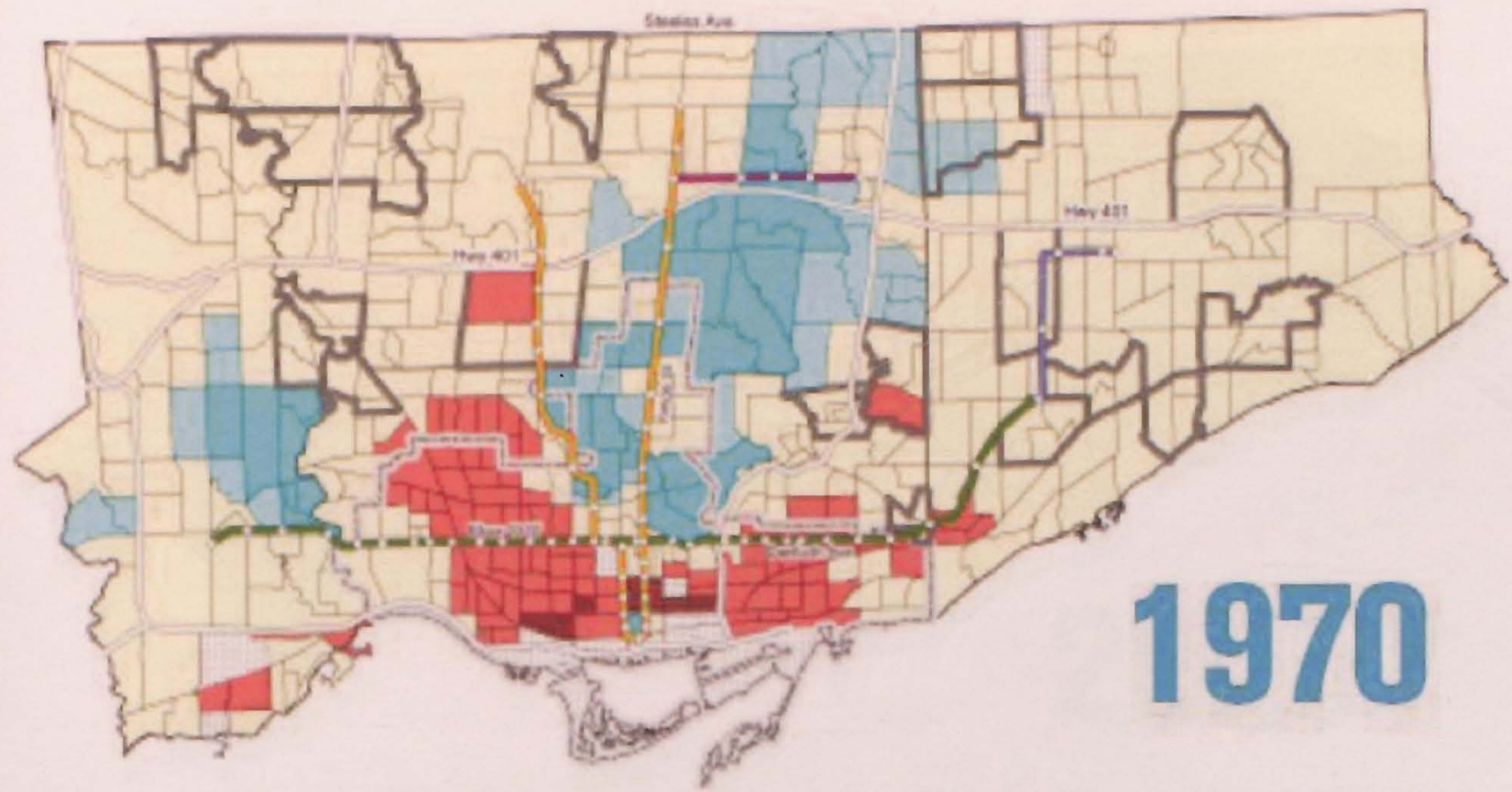

Census Tract Average Individual Income Relative to the Toronto CMA Average of $\$ 30,800^{*}$ (estimated to 2001 census boundaries)

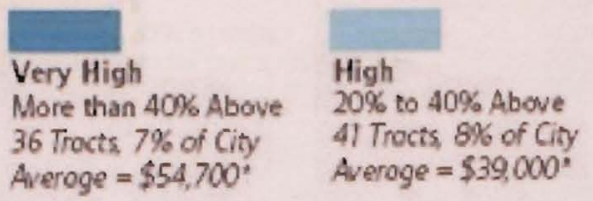

36 Trocts $7 \%$ of City

Averoge $=\$ 54,700^{\circ}$

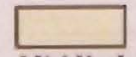

Middle income

$20 \%$ Below to $20 \%$ Above $20 \%$ to $40 \%$ Below

341 Trocts $66 \%$ of City 91 Trosts, $18 \%$ of City

Averoge $=\$ 29,800^{\circ} \quad$ Averoge $=\$ 22,300^{\circ}$
Very Low

More than $40 \%$ Below

6 Trocts, $1 \%$ of City

Averoge $=\$ 17,000^{*}$

* Averoge incomes in constont 2005 dollors 
Appendix 1.C)

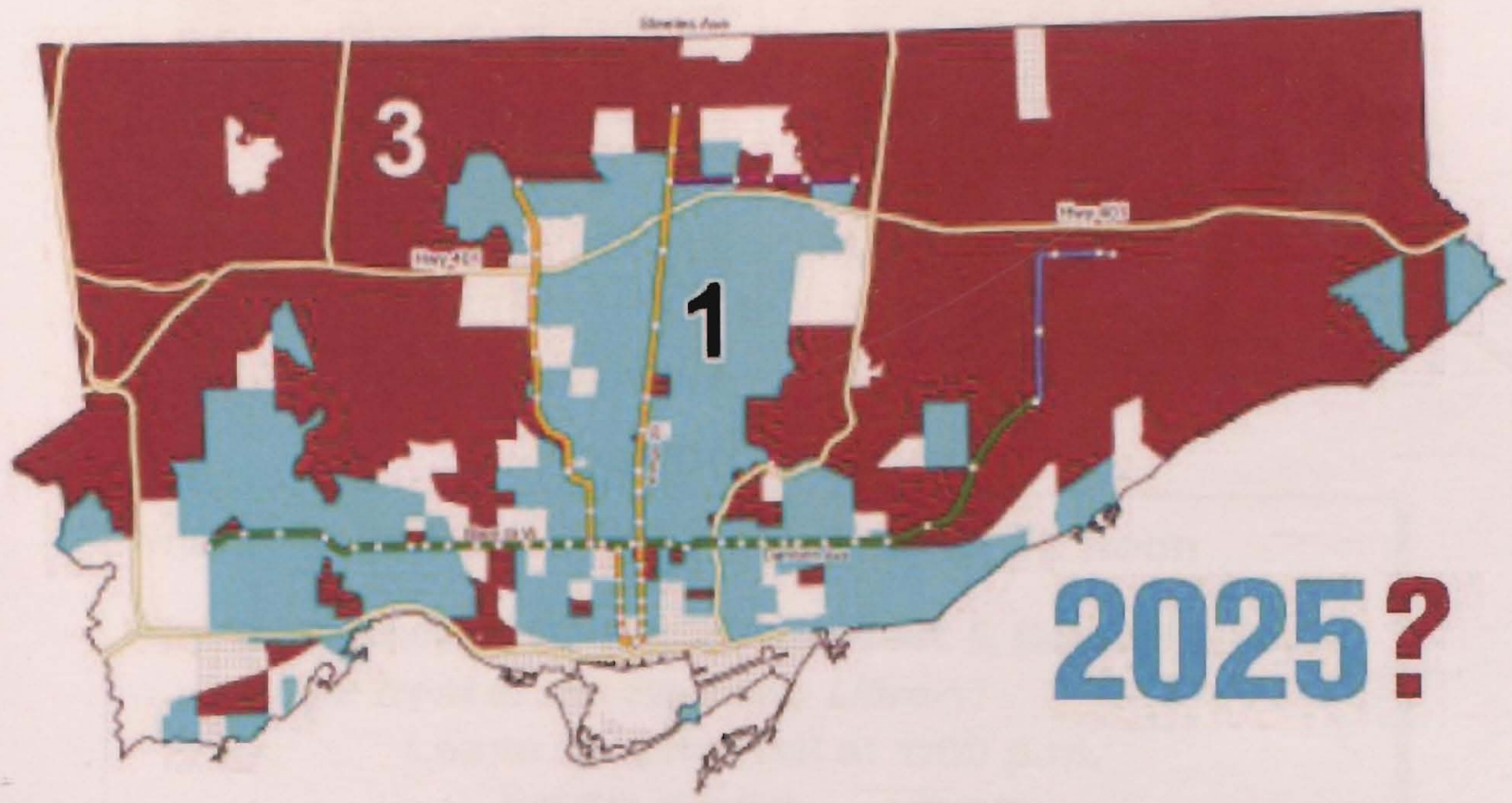

\section{City aा}

Increase of $20 \%$ or more

2025: 156 census trocts, $30 \%$ of City

2005 octuol: 100 census trocts, $19 \%$ of city

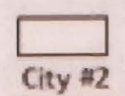

Increase or Decrease is Less than $20 \%$

2025: 50 census trocts $9 \%$ of City

2005 octual: 208 census trocts, $40 \%$ of City
City $\# 3$

Decrease of $20 \%$ or More

2025: 308 census trocts, $60 \%$ of City

2005 actuot 206 census tracts, $40 \%$ of City 


\section{SOCIAL CLEANSING IN PARKDALE}
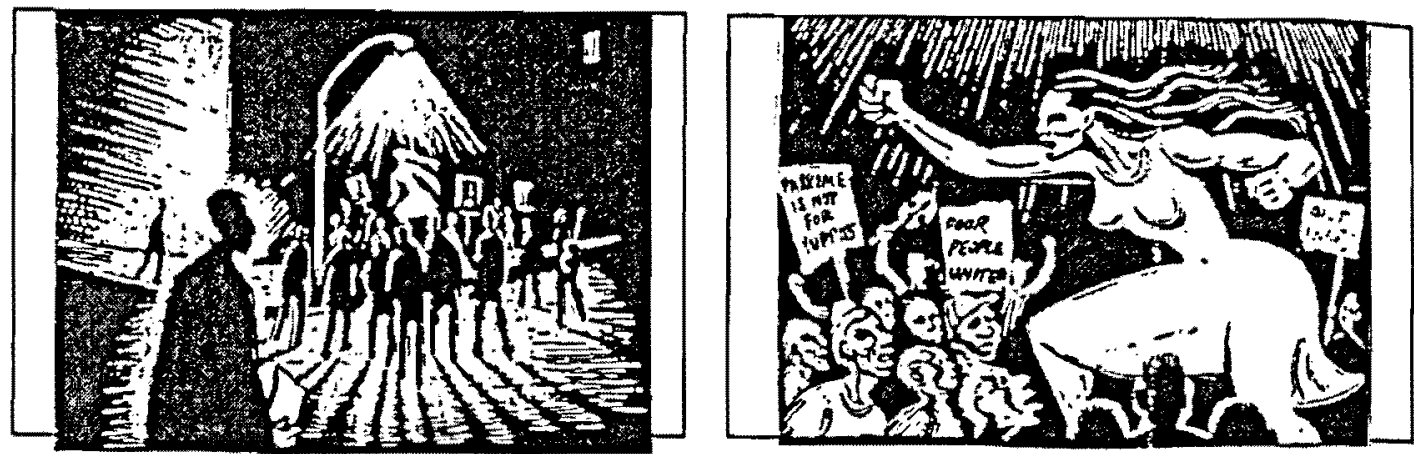

DEMONSTRATION

When: THURSDAY, MAY 13, 1999 at 12 noon

Where: Corner of Queen Street West \& Cowan Avenue (In front of the Parkdale Library)

Leave for City Hall at 1:00 p.m. FREE FOOD and POP

- The City of Toronto is declaring war on the tenants of Parkdale.

- They want to shut down small apartments and rooming houses by enforcing a City "BY-LAW" which prohibits rooming houses and bachelorette apartments. This discriminates against people of low income and disabilities who need this kind of housing. This is Soclal Cleansing.

- The City has already shut down 4 Elm Grove (a bachelorette building) and evicted all the tenants.

- Now they want to shut down other bachelorettes and rooming houses.

- Don't let them get away with this.

- If the city of Toronto is as serious about homelessness as they say they are, they should not shut down any bachelerettes and rooming houses until the crisis in affordable housing is fixed.

- Join us on Thursday, May 13, at 12 Noon at the Corner of Queen and Cowan.

- Join us to visit Mayor Mel Lastman to tell him that if the City of Toronto is serious about homelessness, it should not shut down any bachelorettes or rooming houses. It should fix them up.

FIX THEM UP, DON'T SHUT THEM DOWN

FIX THEM UP, DON'T KICK US OUT

THE COMMON FRONT TO DEFEND POOR NEIGHBOURHOODS

(416) $760-2149$ or (416) $925-6939$

(Slater, 2004) 


\section{REFERENCE LIST}

Allmendinger, P. (2002). Planning Theory. New York: Palgrave.

Atkinson, R. \& Kintrea, K. (2000). Owner-occupation, Social Mix and

Neighbourhood Impacts. Policy and Politics. 28, 93-108.

Barc, A. (2011). Nostalgia Tripping: Trefann Court. Retrieved from

http://www.blogto.com/city/2011/01/nostalgia tripping trefann court/

Brookings Institution. (2011). The Great Recession and Poverty in Metropolitan America.

Retrieved April 3, 2011, from

http://www.brookings.edu/papers/2010/1007 suburban poverty acs kneebone.as $\underline{\mathrm{px}}$

Bunce, S. (2009). Developing sustainability: sustainability policy and gentrification on Toronto's waterfront. Local Environment: 14 (7), 651-667.

Centre for Addiction and Mental Health. (2002). Master Plan Executive Summary.

Retrieved from

http://www.camh.net/News events/Redeveloping the Queen Street site/Master\%20Plan $\% 20$ and\%200ther\%20Documents/camhredev masterexec2003.pdf

Centre for Addiction and Mental Health. (2008). Master Vision. Retrieved from http://www.camh.net/News events/Redeveloping the Queen Street site/Master\%20Plan \%20and\%200ther\%20Documents/080215\%20CAMH\%20Master\%20Vision\%20Final\%20D ocument.pdf

Davidson, M. (2008). Spoiled Mixture: Where Does State-led 'Positive' Gentrification End? Urban Studies: 45(12), 2385-2405.

Davis, M. (1998). Ecology of Fear. New York: Metropolitan Books.

Davis, M. (2006). City of Quartz. New York: Verso.

Fainstein, S., Gordon, I. \& Harloe, M. (1992). Divided Cities. Cambridge, MA: Blackwell Publishers.

Filion, P. (2010). Reviews, Thinking Planning and Urbanism by Beth Moore Milroy. The Canadian Geographer: 54(3), 384-385.

Fortin, V. (2008). Keep Your Coins, I Want Change! The Homeless and the Shrinking Public Space in Montreal. The Law and Society Association. Retrieved from http://www.allacademic.com/meta/p236369 index.html

Gans, H.J. (1982). The Urban Villagers. New York: The Free Press. 
Glasbeek, A. (2006). Moral Regulation and Governance in Canada: History, Context, and Critical Issues. Toronto: Canadian Scholars' Press Inc.

Gordon, T. (2006). Neoliberalism, Racism, and the War on Drugs in Canada. Social Justice: 33(1), 59-79.

Gowan, T. (2009). Lost in Space: The Criminalization, Globalization, and Urban Ecology of Homelessness. Contemporary Sociology: 38(5), 417-419.

Harvey, D. (1989). The Condition of Postmodernity: An Enquiry into the Origins of Social Change. Oxford: Blackwell Publishers.

Harvey, D. (2008). The Right to the City. New Left Review. 53, 23-40.

Homer-Dixon, T. (2011, February). Resiliency. Canadian Association of Planning Students conference. Lecture conducted from the University of Waterloo, Ontario.

Horowitz, C. \& Schachar, S. (2010). Deconstructing the Urban Village: Critical Perspectives on the CAMH Redevelopment Plan. Advanced Theories of Planning, Ryerson University.

Hulchanski, J. (2010). The Three Cities within Toronto: Income Polarization among Toronto's Neighbourhoods, 1970-2000. Centre for Urban \& Community Studies: Research Bulletin, 41.

Jacobs, J. (1961). The Death and Life of Great American Cities. New York: Random House.

Jameson, F. (1991). Postmodernism, or, The Cultural Logic of Late Capitalism.

Durham, NC: Duke University Press.

Larsen, H. \& Hansen, A. (2008). Gentrification-Gentle or Traumatic? Urban Renewal Policies and Socioeconomic Transformations in Copenhagen. Urban Studies: $45(12), 2429-2448$.

Lees, L. (2008). Gentrification and Social Mixing: Towards an Inclusive Urban Renaissance. Urban Studies: 45(12), 2449-2470.

Lees, L. \& Ley, D. (2008). Introduction to Special Issue on Gentrification and Public Policy. Urban Studies: 45(20), 2379-2384. .

Lefebvre, H. (1974). La Production de L'espace. Paris: Anthropos.

Ley, D. \& Dobson, C. (2008). Are There Limits to Gentrification? The Contexts of Impeded Gentrification in Vancouver. Urban Studies: 45(12), 2471-2498.

Mitchell, D. (1997). Annihilation of Space by Law: The Roots and Implications of Anti-Homeless Laws in the United States. Antipode: 29(3), 303-335. 
Moran, J. (2007). Early Cultures of Gentrification in London, 1955-1980. Journal of Urban History: 34(1), 101-121.

Newman, K. \& Wyly, E. (2006). The Right to Stay Put, Revisited: Gentrification and Resistance to Displacement in New York City. Urban Studies:43(1), 23-25.

Raban, J. (1974). Soft City. London: The Harvill Press.

Randolph, B. \& Wood, M. (2003). The benefits of tenure diversification. Australian Housing and Urban Research Institute, Melbourne.

Safe Streets Act, S.O. ch. 8. (1999). Retrieved from

http://www.e-laws.gov.on.ca/html/statutes/english/elaws statutes $99508 \mathrm{ehtm}$

Sandercock, L. (1999). A Portrait of Postmodern Planning: Anti-Hero and/or Passionate Pilgrim? Plan Canada: 39(2), 90-97.

Sandercock, L. (2003). Cosmopolis Il: Mongrel Cities of the 21 $1^{\text {st }}$ Century. New York: Continuum.

Sandercock, L. (2004). Commentary: Indigenous Planning and the Burden of Colonialism. Planning Theory \& Practice: 5(1), 118-124.

Sassen, S. (1999). The Global City: New York, London, Tokyo. Princeton: Princeton University Press.

Sennet, R. (1993). The Uses of Disorder: Personal Identity and City Life. New York: W.W. Norton and Company, Inc.

Sharman, R.L. (2006). The Tenants of East Harlem. London: University of California Press.

Shaw , K. (2008a). A Response to 'The Eviction of Critical Perspectives from Gentrification Research'. International Journal of Urban and Regional Research: 32.1, 192194.

Shaw, K. (2008b). Commentary: Is There Hope for Policy? Urban Studies. 45(12), 26372642.

Slater, T. 2004. Municipally-managed gentrification in South Parkdale, Toronto. The Canadian Geographer: 48(3), 303-325.

Slater, T. (2006). The Eviction of Critical Perspectives from Gentrification Research. International Journal of Urban and Regional Research: 30.4, 737-757.

Slater, T. \& Whitzman, C. (2006). Village Ghetto Land: Myth, Social Conditions, and Housing Policy in Parkdale, Toronto, 1879-2000. Urban Affairs Review: 41, 673-696. 
Smith, N. (1996). The New Urban Frontier: Gentrification and the Revanchist City. New York: Routledge.

Soja, E. J. (2010). Seeking Spatial Justice. Minneapolis: University of Minnesota Press.

Sorkin, M. (2007). The End(s) of Urban Design. Harvard Design Magazine. Spring/Summer, 4-18.

The Economist. (2010). Mortgage or Food: The poverty gap is closing between suburbs and inner-cities. Retrieved April 3, 2011, from http://www.economist.com/node $/ 17257857$ ? story id $=17257857 \& \mathrm{fsrc}=\mathrm{rss}$

United Way. (2011). Poverty by Postal Code 2: Vertical Poverty. Retrieved from http://www.unitedwaytoronto.com/verticalpoverty/report/introduction/

Wacquant, L. (2008). Relocating Gentrification: The Working Class, Science and the State in Recent Urban Research. International Journal of Urban and Regional Research: 32.1, 198-205.

Walks, A. (2006). Homelessness, housing affordability, and the new poverty, in T. Bunting and P. Filion Canadian Cities in Transition, 419-437. Toronto: Oxford University Press.

Walks, A. \& August, M. (2008). The Factors Inhibiting Gentrification in Areas with Little Non-market Housing: Policy Lessons from the Toronto Experience. Urban Studies: $45(12), 2594-2625$.

Yiftachel, O. (1998). Planning and Social Control: Exploring the Dark Side. Journal of Planning Literature: 12, 395.

Zukin, S. (2010). Naked City: The Death and Life of Authentic Urban Places. New York: Oxford University Press.

Zukin, S. (1995). The Cultures of Cities. Oxford: Blackwell Publishers Ltd. 